\title{
Formation of benchmark indicators and the integrated evaluation of territories
}

\author{
Elena Aksenova \\ Don State Technical University \\ Road and Transport Faculty \\ Chair of Environmental Economics and Cadastre \\ Rostov-on-Don, Russia \\ lenochek-1512@yandex.ru
}

\author{
Aleksei Aksenov \\ Don State Technical University \\ Faculty of Information and Economic Systems \\ Chair of Economic Theory and Entrepreneurship \\ Rostov-on-Don, Russia \\ alexey_2002@mail.ru
}

\author{
Olga Shevchenko \\ Don State Technical University \\ Road and Transport Faculty \\ Chair of Environmental Economics and Cadastre \\ Rostov-on-Don, Russia \\ djanchik80@mail.ru
}

\begin{abstract}
The development of the economy and the state of the natural environment in the cities are closely interrelated, which necessitates the development of an organizational mechanism for the use of landscapes, based on methods for planning and forecasting the development of territories. In order to rationally, sustainably and economically use the territorial potential, as well as to obtain a realistic picture of the functioning and management of urban landscapes, an integrated evaluation is needed, which includes all areas of urban development. Complex evaluation, being a powerful tool in the system of territorial planning, allows to develop proposals for the sustainable development of the municipal formation. The primary task of the integrated evaluation is the formation of its indicators. In the work, a system of generalized criterial indices of complex estimation is formed, which allows to analyze the current state of the territories, and also to forecast the possibility of their development.
\end{abstract}

Keywords - integrated evaluation, benchmark indicators, organizational mechanism, rational use of territories, planning, forecasting

\section{INTRODUCTION}

In modern conditions, the problem of rational use of territories is very important. It should be borne in mind that the process of urbanization is caused by limiting conditions and excessive concentration of industrial enterprises in limited spaces [1]. In this case, the issue of achieving an equilibrium of environmental, social and economic factors in the process of organizing and using the territories is acute.

In the organizational system of functioning of the territory and management of its development processes, a special type of activity called planning is applied. The organization of a system for planning and using territories, both in the city and in the region as a whole, depends on many factors, including:

- urban zoning, which is an instrument for managing territories aimed at rationalizing their use;

- implementation of design solutions for the arrangement and improvement of landscapes;

- investment attractiveness of the territories;

- participation of specific territories in solving state tasks in the area of the allocation of productive forces.

The quantitative and qualitative composition of the territories, obtained through a comprehensive assessment, makes it possible to determine the long-term prospects for their development in the industrial, economic and social areas [2].

Analysis of literary sources showed that the methodological foundations of socio-ecological and economic evaluation of the state of built-up areas are considered in the writings of such scientists as V.I. Bespalov, A.P. Moskalenko, Yu.Yu. Maksyukova, V.P. Petrischev, S.A. Dubrovskaya. The questions of regulation of urban-planning activity are reflected in the scientific works of S.G. Sheina, L.L. Babenko, R.B. Matveyko. Separate aspects of determining the socioecological and economic efficiency of the territory are laid down in A.Yu. Davankov, T.A. Vereshchagina, M.A. Gryazev.

The methodological basis for conducting a comprehensive environmental and economic evaluation of the state of urban areas is reflected in the thesis of E.G. Aksenova, and 
assessments of the ecological condition of the city for the purposes of urban planning regulation - E.P. Sokolova.

At the same time, there are still many unexplored issues concerning the generalized evaluation of urbanized areas in four key areas: ecological, economic, social and urban development, which makes the topic of this study relevant.

The purpose of the study is to develop criteria for integrated evaluation of the territory, conducted to implement solutions in the field of planning system for competitive, sustainable and safe development of territorial entities.

The combination of numerous factors in the development of the territory determines the planning restrictions on its use, and the analysis of these factors makes it possible, with the help of a comprehensive evaluation, to differentiate territories according to suitability for town planning purposes into an unusable, limited and wide range of uses [3]. Rational use of territories is a guarantee of competitive, sustainable and safe development of the region.

The main objective of the study is to select criteria that allow for a comprehensive evaluation of the territories, depending on the objectives of its implementation.

\section{MATERials And Methods (Model)}

There is no single template methodology for conducting a comprehensive evaluation of the territory. This is explained by the fact that the formation of criterial indicators depends on the purposes for which it is conducted.

In the system of planning for competitive, sustainable and safe development of the territories of the region, there is a need to assess their social, economic and environmental status. Considering the growth rates of urbanized spaces, it is worth paying attention to the urban development value of the territories [4]. The development of landscapes according to their functional and territorial features is based on the principles of territory planning, among which the most important is the provision of favorable conditions for the population to live.

In order to efficiently and harmoniously use territorial resources, the balanced nature of the relationship between man and the biosphere, the preservation of the genetic diversity of living organisms, recommendations and proposals are needed that can be divided into four blocks: economic, environmental, social and urban planning [5]. Thus, it is proposed to select of benchmark indicators for four areas of use and development of territories [6], each of which can be divided into evaluation blocks: I block - on the factor of accessibility of infrastructure objects and their impact on the territory, II block - by quantitative characteristics of the territory, III block - on qualitative characteristics of the territory, IV block depending on the influence of exogenous factors, V block indicators of long-term development. The number of evaluation blocks for each direction for compiling the calculation matrix should be the same and similar either in terms of the degree of impact on certain aspects of the development of the territories or the degree of vulnerability of certain funds and objects (Table I). A comprehensive evaluation makes it possible to analyze individual indicators allocated to enlarged blocks depending on the purposes of planning and forecasting the use of territories.

At the planning stage of further use of the territories, environmental measures are taken into account, which require significant financial costs. For their implementation, both budgetary funds and private investments are attracted, while the degree of financial risks should be minimal [7]. A comprehensive evaluation of the territories will reduce the likelihood of financial losses at the planning stage of environmental measures, since all possible factors that directly or indirectly affect the further development of the territories are taken into account [8].

\section{RESULTS AND DISCUSSION}

Evaluation criteria for each indicator, selected in accordance with the current specifics of the use of territories are summarized first for each allocated block, and then incommon value. Calculation of the final integrated assessment of the territory $(\mathrm{P})$ is presented in the form of table II.

The result of the evaluation for each individual block makes it possible to identify the most vulnerable area in the use of territories and to develop measures that will quickly and cost-effectively restore their value [9].

The analysis of the territories obtained as a result of the comprehensive assessment taking into account the specifics of the existing and further long-term planning of its use makes it possible to attribute the assessed areas of the territory to certain zones identified by the degree of value.

In the case when an evaluation of territorial resources with a pronounced man-caused load is being carried out, most of the area occupied by industrial zones and territories of the greatest industrial activity, the weight factor of the estimated factor should be introduced [10]. In the system of planning competitive, sustainable and safe development of the territories of the region, this is the coefficient of ecological importance of the region. 
TABLE I. INDICATORS OF INTEGRATED EVALUATION OF URBAN TERRITORIES

\begin{tabular}{|c|c|c|c|c|}
\hline \multirow{2}{*}{$\begin{array}{c}\text { Evaluation } \\
\text { blocks }\end{array}$} & \multicolumn{4}{|c|}{ Direction of evaluation (assigned a points for each criterion) } \\
\hline & Economical & Ecological & \begin{tabular}{|r|} 
Social \\
\end{tabular} & Urban development \\
\hline I block & \begin{tabular}{l}
\multicolumn{1}{c}{ Organization and } \\
development of production \\
1) conformity of labor \\
potential to personnel \\
demand \\
2) availability of retail space \\
and centers \\
3) availability of financial \\
capital \\
4) availability of commodity \\
markets \\
5) the development of \\
market infrastructure
\end{tabular} & $\begin{array}{l}\text { Assessment of air pollution } \\
\text { Depends on the total indicator } \\
\text { of pollutants } C_{i} \\
\qquad S=\frac{\sum_{i=1}^{n} S_{i}}{n} \\
\text { where the result of the evaluation } \\
\text { S- the total score for the evaluation block, } \\
\quad S_{i} \text { - point for the } i \text {-th pollutant } \\
\text { 1) } \mathrm{C}_{\mathrm{i}}=0-5 \text { points } \\
\text { 2) } \mathrm{C}_{\mathrm{i}} \leq 35 \% * \mathrm{MAC}_{\mathrm{i}}-4 \text { points } \\
\text { 3) } 35 \% * \mathrm{MAC}_{\mathrm{i}}<\mathrm{C}_{\mathrm{i}} \leq 70 \% * \mathrm{MAC}_{\mathrm{i}}-3 \text { points } \\
\text { 4) } 70 \% * \mathrm{MAC}_{\mathrm{i}}<\mathrm{C}_{\mathrm{i}}<\mathrm{MAC}_{\mathrm{i}}-2 \text { points } \\
\text { 5) } \mathrm{C}_{\mathrm{i}}=\mathrm{MAC}_{\mathrm{i}}-1 \text { point } \\
\text { 6) } \mathrm{C}_{\mathrm{i}}>\mathrm{MAC} \mathrm{C}_{\mathrm{i}}-0 \text { point } \\
\text { rдe MAC }- \text { maximum allowable } \\
\text { concentration }\end{array}$ & $\begin{array}{l}\text { Estimation of the capacity of facilities to } \\
\quad \text { meet the needs } \\
\text { 1) the correspondence of objects } \\
\text { providing the needs of the population to } \\
\text { the projected number of inhabitants } \\
\text { 2) the availability of means of } \\
\text { transportation for the less mobile groups } \\
\text { of the population } \\
\text { 3) availability of multifunctional centers } \\
\text { in pedestrian accessibility } \\
\text { 4) availability of means of } \\
\text { communication and mass information } \\
\text { communications } \\
\text { 5) the radius of objects to meet the needs } \\
\text { of the population is not more than } 500 \mathrm{~m}\end{array}$ & $\begin{array}{l}\text { Evaluation of the level of } \\
\text { development of the engineering } \\
\text { infrastructure of the territory } \\
\text { 1) electricity supply } \\
\text { 2) water supply and water } \\
\text { disposal } \\
\text { 3) gas supply } \\
\text { 4) sewerage } \\
\text { 5) heat supply }\end{array}$ \\
\hline II block & $\begin{array}{l}\text { Economic development of } \\
\quad \text { the region } \\
\text { 1) the dynamics of the gross } \\
\text { regional product per capita } \\
\text { 2) gross accumulation per } \\
\text { capita } \\
\text { 3) profit of activities of } \\
\text { organizations per employee } \\
\text { 4) level of profitability of the } \\
\text { main spheres of the economy } \\
\text { 5) dynamics of net exports }\end{array}$ & $\begin{array}{l}\text { Evaluation of the state of biodiversity and } \\
\quad \text { landscape } \\
\text { 1) the presence of ecological corridors } \\
\text { 2) the presence of forest tracts and } \\
\text { recreational zones } \\
\text { 3) species diversity of landscapes } \\
\text { 4) availability of agro-cultural landscapes } \\
\text { 5) presence of the cartographic basis of } \\
\text { the territory }\end{array}$ & $\begin{array}{l}\text { Estimation of the aesthetic perception of } \\
\quad \text { the territory } \\
\text { 1) the availability of attractions } \\
\text { 2) presence of ecotrip } \\
\text { 3) availability of aquaculture territories } \\
\text { 4) the availability of observation } \\
\text { platforms } \\
\text { 5) the existence of objects of artistic and } \\
\text { creative development }\end{array}$ & 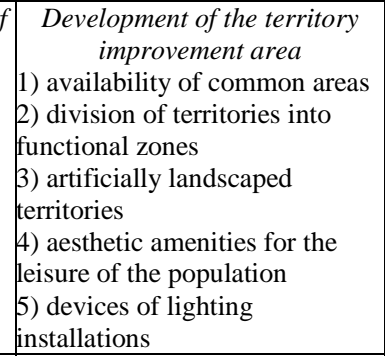 \\
\hline III block & $\begin{array}{l}\text { Level and quality of life of the } \\
\quad \text { population } \\
\text { 1) population income } \\
\text { dynamics } \\
\text { 2) expenditures and } \\
\text { consumption by the } \\
\text { population of material goods } \\
\text { and services } \\
\text { 3) the level of savings } \\
\text { 4) the amount of accumulated } \\
\text { property } \\
\text { 5) housing security }\end{array}$ & $\begin{array}{l}\text { Characteristics of the hydrographic } \\
\text { network } \\
\text { 1) on the basis of pollutants in accordance } \\
\text { with MPC } \\
\text { 2) the presence of natural natural reservoirs } \\
\text { 3) the presence of artificially created } \\
\text { reservoirs } \\
\text { 4) the presence of water protection zones } \\
\text { 5) the existence of existing programs to } \\
\text { protect and restore the water basin }\end{array}$ & $\begin{array}{l}\text { Historical and cultural significance of } \\
\text { the territory } \\
\text { 1) monuments of architecture and art } \\
\text { 2) objects of cultural heritage } \\
\text { 3) museums and state archives } \\
\text { 4) historical buildings } \\
\text { 5) archaeologically significant territories }\end{array}$ & \begin{tabular}{l}
\multicolumn{1}{c}{$\begin{array}{c}\text { Evaluation of an available } \\
\text { housing }\end{array}$} \\
1) the historical framework of \\
the planning structure \\
2) the absence of dilapidated \\
housing \\
3) absence of servitudes \\
4) the existence of targeted \\
programs for the development of \\
housing stock \\
5) availability of state or \\
municipal housing stock
\end{tabular} \\
\hline IV block & $\begin{array}{l}\text { Formation of prices for real } \\
\quad \text { estate objects } \\
\text { 1) dynamics of economic } \\
\text { growth rates } \\
\text { 2) rates of inflation } \\
\text { 3) the change in the dollar } \\
\text { exchange rate } \\
\text { 4) growth of real incomes of } \\
\text { the population } \\
\text { 5) change in the purchasing } \\
\text { power of the currency }\end{array}$ & $\begin{array}{l}\quad \text { Assessment of the radiation state } \\
\text { 1) the absence of radionuclides in the near- } \\
\text { surface and deep-lying } \\
\text { 2) the absence of zones and areas of } \\
\text { atmogeochemical (radon, helium, thoron) } \\
\text { anomalies } \\
\text { 3) the availability of shelters and protective } \\
\text { structures } \\
\text { 4) availability of radiation and hygienic } \\
\text { passports of organizations and territories } \\
\text { 5) the radiation level does not exceed MAC }\end{array}$ & $\begin{array}{l}\text { Assessment of environmental culture and } \\
\quad \text { education of the population } \\
\text { 1) the availability of libraries for different } \\
\text { age groups } \\
\text { 2) a common information and } \\
\text { environmental space } \\
\text { 3) the existence of trade union } \\
\text { organizations } \\
\text { 4) public organizations responsible for } \\
\text { environmental education } \\
\text { 5) existing target programs for } \\
\text { environmental protection }\end{array}$ & $\begin{array}{l}\text { Evaluation of the factor of } \\
\text { recreational value of } \\
\quad \text { territories } \\
\text { 1) availability of recreational } \\
\text { areas necessary for the area } \\
\text { 2) resort areas } \\
\text { 3) development of tourist } \\
\text { destinations } \\
\text { 4) the presence of dendrology } \\
\text { and botanical gardens } \\
\text { 5) recreation and sports areas }\end{array}$ \\
\hline V block & $\begin{array}{l}\begin{array}{l}\text { Evaluation of indicators of } \\
\text { the residential real estate } \\
\quad \text { market }\end{array} \\
\text { 1) growth rates of effective } \\
\text { demand } \\
\text { 2) implementation of } \\
\text { housing programs in the } \\
\text { region } \\
\text { 3) regional support for } \\
\text { construction projects } \\
\text { 4) presence of "entrance } \\
\text { barriers" in the industry } \\
\text { 5) stimulation of investment } \\
\text { activity in housing } \\
\text { construction }\end{array}$ & $\begin{array}{l}\quad \text { Evaluation of the state of soils } \\
\text { 1) absence of mobile sands } \\
\text { 2) lack of active microbial biomass } \\
\text { 3) the presence of a humus horizon in the } \\
\text { soil } \\
\text { 4) absence of fragmentary-fracture } \\
\text { structure in soils } \\
\text { 5) absence of land withdrawn from land use }\end{array}$ & $\begin{array}{l}\text { Evaluation of social and cultural objects } \\
\text { 1) the existence of objects of social } \\
\text { culture } \\
\text { 2) the availability of educational } \\
\text { institutions } \\
\text { 3) the availability of health facilities } \\
\text { 4) availability of information security } \\
\text { institutions } \\
\text { 5) compliance with fire safety } \\
\text { requirements at social and cultural sites }\end{array}$ & \begin{tabular}{l}
\multicolumn{1}{c}{$\begin{array}{c}\text { Evaluation of transport } \\
\text { infrastructure }\end{array}$} \\
1) developed pedestrian \\
network \\
2) transport accessibility to \\
industrial zones \\
3) developed railway network \\
4) availability of public \\
transport \\
5) availability of road service \\
facilities
\end{tabular} \\
\hline
\end{tabular}


TABLE II. CALCULATION OF THE FINAL COMPLEX EVALUATION OF THE TERRITORY

\begin{tabular}{|c|c|c|c|c|c|c|c|}
\hline $\begin{array}{c}\text { Type of } \\
\text { evaluation }(\mathbf{j})\end{array}$ & I & II & III & IV & $\mathbf{V}$ & $\begin{array}{c}\text { The result } \\
\text { of the } \\
\text { evaluation } \\
\text { by } \mathbf{j}\left(\mathbf{P}_{\mathbf{j}}\right)\end{array}$ & $\begin{array}{c}\text { Maximal } \\
\text { criterion of } \\
\text { evaluation } \\
\text { (points) }\end{array}$ \\
\hline $\begin{array}{l}\text { Economic } \\
\text { evaluation } \\
\text { blocks (X) }\end{array}$ & $\mathrm{X}_{1}$ & $\mathrm{X}_{2}$ & $\mathrm{X}_{3}$ & $\mathrm{X}_{4}$ & $\mathrm{X}_{5}$ & & 25 \\
\hline $\begin{array}{l}\text { Environmental } \\
\text { evaluation units } \\
\text { (Y) }\end{array}$ & $\mathrm{Y}_{1}$ & $\mathrm{Y}_{2}$ & $\mathrm{Y}_{3}$ & $\mathrm{Y}_{4}$ & $\mathrm{Y}_{5}$ & & 25 \\
\hline $\begin{array}{l}\text { Social } \\
\text { evaluation } \\
\text { blocks (Z) }\end{array}$ & $\mathrm{Z}_{1}$ & $\mathrm{Z}_{2}$ & $\mathrm{Z}_{3}$ & $\mathrm{Z}_{4}$ & $\mathrm{Z}_{5}$ & & 25 \\
\hline $\begin{array}{l}\text { Urban } \\
\text { development } \\
\text { appraisal blocks } \\
\text { (G) }\end{array}$ & $\mathrm{G}_{1}$ & $\mathrm{G}_{2}$ & $\mathrm{G}_{3}$ & $\mathrm{G}_{4}$ & $\mathrm{G}_{5}$ & & 25 \\
\hline Total & & & & & & & 100 \\
\hline
\end{tabular}

where: $P_{j}-$ the result of an evaluation of the territory by type of evaluation;

$X_{i,} Y_{i,} Z_{i,} G_{i}$ - estimated score by type of evaluation;

$n$ - number of evaluation blocks equal to 5 .

\section{CONCLUSIONS}

Integrated evaluation provides an opportunity to identify the most vulnerable aspects in the use of territories, develop proposals for their elimination and organization of rational use of landscapes, namely:

- determine the impact of the location and development of productive forces on the state of the environment;

- ensure the compliance of the infrastructure and planning organization of the territory;

- eliminate inconsistencies in the system of planning and forecasting the development of landscapes;

- calculate the economic efficiency of a rational organization of landscapes;

- develop programs and activities to develop the housing market and the formation of social protection of the population [11].

The results of the integrated evaluation are to be compared with the data of the scale of the value characteristic of the urban area, presented in Table III.

The materials obtained as a result of the integrated evaluation allow to develop proposals on the reduction of ecological and economic risks in the development of the territories, namely:
- to determine the impact of technogenic load, resulting in a number of negative impacts, ranging from urban landscapes ubiquitous pollution with production and consumption wastes and ending with social distortions in municipalities;

- ensure the compliance of the infrastructure component of the urban areas of their planning organization, which will make the most effective use of the territorial potential of the locality, increase tax revenues to local budgets, and improve the comfort level of the urban environment;

- eliminate the problems associated with the implementation of strategic territorial planning documents through the formation of geospatial data for the integrated development of the municipal formation;

- develop targeted programs for the protection of the environment and natural resources [12].

TABLE III. SCALE OF VALUE CHARACTERISTICS OF THE TERRITORY

\begin{tabular}{|c|c|c|c|}
\hline \begin{tabular}{|c|} 
The result of \\
the integrated \\
evaluation \\
(points) \\
\end{tabular} & $\begin{array}{c}\text { Degree of } \\
\text { evaluation }\end{array}$ & $\begin{array}{c}\text { Priority directions of } \\
\text { development of } \\
\text { territories }\end{array}$ & Recommended activities \\
\hline $81-100$ & $\begin{array}{c}\text { Highest } \\
\text { grade }\end{array}$ & $\begin{array}{c}\text { Areas suitable for } \\
\text { competitive, sustainable } \\
\text { and safe development }\end{array}$ & $\begin{array}{l}\text { Determination of the } \\
\text { objectives of further } \\
\text { economic activity in the } \\
\text { evaluation territories }\end{array}$ \\
\hline $61-80$ & $\begin{array}{l}\text { Relatively } \\
\text { high grade }\end{array}$ & $\begin{array}{l}\text { Areas suitable for } \\
\text { forming zones of } \\
\text { dynamic economic } \\
\text { growth }\end{array}$ & $\begin{array}{c}\text { Identification of } \\
\text { inconsistencies in the } \\
\text { landscape planning and } \\
\text { prediction system }\end{array}$ \\
\hline $41-60$ & $\begin{array}{c}\text { Average } \\
\text { grade }\end{array}$ & $\begin{array}{l}\text { Areas suitable for } \\
\text { creating conditions for } \\
\text { recreation, restoring } \\
\text { health, building low- } \\
\text { rise buildings and } \\
\text { buildings of medium } \\
\text { height }\end{array}$ & $\begin{array}{l}\text { Development of targeted } \\
\text { long-term programs that } \\
\text { allow timely } \\
\text { implementation of } \\
\text { environmental protection } \\
\text { measures }\end{array}$ \\
\hline $21-40$ & $\begin{array}{l}\text { Relatively } \\
\text { low grade }\end{array}$ & \begin{tabular}{|} 
Territories on which it \\
is necessary to carry out \\
measures for their \\
protection and \\
restoration
\end{tabular} & $\begin{array}{l}\text { The development of } \\
\text { tengineering infrastructure } \\
\text { the attraction of } \\
\text { manpower resources with } \\
\text { the appropriate } \\
\text { qualifications, } \\
\text { development of } \\
\text { recreational areas }\end{array}$ \\
\hline менее 20 & Low grade & $\begin{array}{l}\text { Territories that do not } \\
\text { meet the requirements } \\
\text { of competitive, } \\
\text { sustainable and safe } \\
\text { development of the } \\
\text { region, unfit for } \\
\text { construction purposes }\end{array}$ & $\begin{array}{c}\text { Modernization of } \\
\text { equipment, application of } \\
\text { new technologies in the } \\
\text { technical organization of } \\
\text { territorial space, } \\
\text { solution of problems of } \\
\text { engineering and social } \\
\text { infrastructure }\end{array}$ \\
\hline
\end{tabular}

Compliance with and implementation of the proposed activities based on the results of the evaluation contributes to the planning organization of competitive, sustainable and safe development of the territories and the region as a whole. 


\section{References}

[1] O.Yu. Shevchenko, E.G. Aksenova, A.S. Tkachenko, "Influence of the development and placement of productive forces on the state of the surrounding environment" / O.Yu. Shevchenko, E.G. Aksenova, A.S Tkachenko. ELIBRARY.RU. Economics and ecology of territorial entities. 2016. № 2. - P. 86-90.

[2] E.G. Aksenova, "Principles of strategic development of the territorial structure of the municipality" / E.G. Aksenova, In the collection: Integration processes in the modern geo-economic space: Materials of the scientific-practical conference. 2016. P. 8-12.

[3] S.G. Sheina, L.L. Babenko, R.B. Matveyko, A.A. Khamavova, "Comprehensive assessment of the territory in urban planning". Monograph. Rostov-on-Don, 2014. - 100 with.

[4] E.P. Sokolova, "Evaluation of the ecological state of the city for the purposes of town planning regulation" / E.P. Sokolova, the author's abstract of the thesis of the candidate of geographical sciences / Moscow State University. M.V. Lomonosov Moscow State University. Moscow, 2008.

[5] E.G. Aksenova, "Criteria of ecological and economic efficiency of nature protection activity in urban conditions" / E.G.Aksenova, The engineer's messenger of the Don. 2012. №4.

[6] D.B. Volgin, "Methodology of a factor-based ecological assessment of urban territory" // Exact Science. 2017. No.11. P.85.
[7] A.P. Moskalenko, "Social and ecological and economic mechanism of investment decisions in nature management" [Text]: monograph. Novocherkassk: UOC "Nabla" YURSTU (NPI). - 2004. - 313 p.

[8] A.Yu. Davankov, T.A. Vereshchagina, M.A. Griazev, "Socioecological and economic efficiency of the territory" // Economic analysis: theory and practice. 2010. № 12. With. 11-18.

[9] V.P. Petrishchev, S.A. Dubrovskaya, "Methodology for a comprehensive assessment of the ecological state of urban areas" // Izvestiya of the Samara Scientific Center of the Russian Academy of Sciences. 2013. T.15. №3. P.234-238.

[10] E.G. Aksenova, "Comprehensive ecological and economic assessment of the state of urban areas in order to ensure a sustainable system of nature management" / E.G. Aksenova, the author's abstract of the dissertation of a Cand.Econ.Sciences: 08.00.05 / Rostov State Building University. Rostov-on-Don. 2013. 24 p.

[11] A.A. Aksenov, "The housing market and formation of social protection of the population": the dissertation of the candidate of economic sciences. North Caucasus Academy of Public Administration, Rostovon-Don, 2004.

[12] V.I. Bespalov, Yu.Yu. Maksyukova, "A method of complex socioecological and economic assessment of the state of built-up territories" / V.I. Bespalov, Yu.Yu. Maksyukova, Human ecology. 2007. №04. P.17-19. 